UDC $347.77 / .78-049.7$

DOI https://doi.org/10.32837/apdp.v0i92.3254

T. I. Begova

\title{
FEATURES OF USE OF INTELLECTUAL PROPERTY OBJECTS: LEGAL BASES AND PROCEDURE
}

Formulation of the problem. At the present stage of development of the world economy, the issue of commercialization of intellectual property is relevant, the introduction of intellectual property in the statutory fund of enterprises is becoming more common, and so on.

However, the problem now is that the results of intellectual work, expressed in intellectual property, although they should bring tangible income, but not always in practice. A necessary prerequisite for profit is the use of property, its introduction into economic circulation.

Legal introduction into economic circulation of results of scientific and technical activity, including objects of intellectual property, is possible only after registration in the order of the property rights established by the state. Otherwise, protection against unfair competition, as well as relations on the transfer of rights with the receipt of material benefits, become impossible.

Unfortunately, legal research in the field of use of intellectual property in the production and sale of competitive products in a market economy and, accordingly, the mechanisms of their legal protection is critically small.

That is why we consider important and relevant analysis of the legal nature and forms of use of such objects.

Research analysis. Problems of legal regulation of relations in the field of intellectual property are covered in the scientific works of V. Kryzhna, V. Milash, O. Yavorska, I. Yakubivsky and others. The issues of the place of such agreements among civil law or commercial agreements, the division of agreements in the field of intellectual law according to various criteria, the state registration of these agreements and other aspects are studied. However, as of today, there are still problems with the application of intellectual property law.

Therefore, the purpose of our article is to reveal the main legal mechanisms for the use of intellectual property.

Presenting main material. Legal regulation of the use of intellectual property is based on the Civil Code of Ukraine, the Commercial Code of Ukraine, the Laws of Ukraine 'On protection of rights to inventions and utility models', 'On protection of rights to industrial designs', 'On protection of trademark rights for goods and services'. 'On protection of plant variety rights', 'On protection of rights to indicate the origin of goods', 'On protection of rights to topography of integrated circuits', 'On copyright and related rights', 'On protection of economic competition', 'On distribution of copies of audiovisual works and phonograms', 'On the peculiarities of state regulation of economic entities related to the production, export, import of disks for laser reading systems.' 
It is advisable to start your research by determining what exactly is to be used, ie what specific types of objects can be used, and what are the features of their use.

The analysis of the civil legislation gives grounds to assert that all objects of the intellectual property right can be conditionally divided into the following types:

1. Objects of industrial property (inventions, utility models, industrial designs, trademarks or marks for goods and services, geographical indications, brand names);

2. Non-traditional objects of intellectual property (plant varieties, animal breeds, layout (topography) of integrated circuits, trade secrets, scientific discoveries, innovation proposals);

3. Objects of copyright and related rights (literary works, works of art, computer programs, data compilation, performance, phonograms and videograms, programs of broadcasting organizations).

It should be noted that this list is not closed and is quite complete. Over time, more and more intellectual property.

Ways of using intellectual property are enshrined in Art. 426 of the Civil Code of Ukraine. It also enshrines one of the main postulates of the procedure for the transfer of intellectual property rights: the use of intellectual property by another person is carried out with the permission of the person who has the exclusive right to allow its use, except in cases of lawful use without such permission.

In this case, the methods of use, its forms are not regulated. The legislator only indicates that these methods must comply with the law.

The conditions for granting a permit (license) for the use of an object of intellectual property rights may be determined by a license agreement, which is concluded in accordance with the requirements of the law. Types of agreements on the disposal of intellectual property rights and requirements for them are contained in Art. 1107-1129 of the Central Committee of Ukraine.

The legislation provides for the main ways of using an invention, utility model or industrial design in the field of management. These include:

1) manufacture, offer for sale, introduction into economic (commercial) circulation, use, import or storage for the specified purpose of a product protected in accordance with the law;

2) application of a method protected in accordance with the law, or offering it for use in Ukraine under the conditions provided by the Central Committee of Ukraine;

3) offering for sale, introduction into economic (commercial) circulation, use, import or storage for the specified purpose of a product manufactured directly in a manner protected in accordance with the law.

Ways to use the trademark are enshrined in Art. 157 of the Civil Code of Ukraine is its use on goods and services for which it is registered, on the packaging of goods, in advertising, printed publications, on signs, during the display of exhibits at exhibitions and fairs held in Ukraine, in brochures, invoices , on forms and in other documentation related to the introduction of these goods and services in economic (commercial) circulation.

Using the geographical indication of the business entity in accordance with the provisions of Art. 160 of the Civil Code of Ukraine are: its use on the goods 
for which this geographical indication is registered, as well as on the packaging; use in advertising, brochures, invoices, printed publications, official forms, signs, etc.

Chapter 75 of the Civil Code of Ukraine regulates the main types of agreements on the disposal of intellectual property rights. Yes, according to Art. 1107 of the Central Committee of Ukraine the order of property rights of intellectual property is carried out on the basis of such agreements:

1) license to use the object of intellectual property rights;

2) license agreement;

3) agreement on the creation by order and use of the object of intellectual property rights;

4) agreement on the transfer of exclusive intellectual property rights;

5) another agreement on the disposal of intellectual property rights.

Detailed consideration of certain types of agreements on the disposal of intellectual property rights is not a direct subject of our study, so we note only what features they have.

The features of agreements on the disposal of intellectual property rights are as follows:

1) the object of the contract itself is special - intangible benefits. In this case, they may be the object of the contract, provided that they are expressed in such an objective form that allows not only to reproduce but also to reproduce them;

2) the second difference from other civil law agreements is the fact that the use of an intellectual property object is possible only on the basis of a user agreement with the right holder of the specified object. In this case, any non-contractual use of the object of the current legislation is recognized as a violation of the rights to this object;

3 ) in addition, a feature of contracts for the use of intellectual property is their paid nature. The right of the owner may grant permission for the free use of such facilities, but in the vast majority of cases, these agreements are concluded on a fee basis, as there is a certain logic of their use;

4) significant restrictions are contained in the legislation on the use of intellectual property, which are duly recognized as secret. In this case, a rather peculiar in comparison with other objects of civil law is the situation when the so-called free use of intellectual property is allowed, which is also considered legitimate: use of these objects by any person who is not a subject of intellectual property rights;

5) the peculiarities of these agreements should also include the fact that one of the points of such an agreement is the results of intellectual property. Moreover, as noted by 0.V. Dzera, the subject of such agreements should be only the results recognized as objects of legal protection, but this does not preclude the possibility of concluding a contract and the result that is not such an object [1, p. 835].

There is an opinion among scientists that commercialization through the use of intellectual property in their own production is the most profitable in terms of profit. Its reliability is partially confirmed by the data of experts who claim that $70-80 \%$ of the market value of companies are the latest technologies and objects of intellectual property rights [2, p. 246]. And this is logical, because all the profit from the sale of intellectual property remains with their right holder. 
The law provides for the possibility of using intangible assets (including intellectual property) in the formation of the authorized capital of new companies. Thus, intellectual property can be contributed to the authorized capital instead of property, money and other material values, which requires only the consent of all founders. It should be emphasized that the use of intellectual property in the authorized capital allows, as noted by B.G. Prakhov:

1) generate significant authorized capital without diversion of funds and provide access to bank loans and investments, using intellectual property as collateral along with other types of property;

2) depreciate intellectual property in the authorized capital and replace it with real funds, including depreciation deductions on the cost of production, ie capitalize intellectual property;

3) authors and enterprises-owners of intellectual property - to become founders (owners) in the organization of subsidiaries and independent firms without branching [3, p. 72].

The introduction of intellectual property rights to the authorized capital instead of real funds also provides: the right to receive a share of profits (dividends); the right to participate in the management of the enterprise through the general meeting of the board; the right to receive a liquidation quota in case of liquidation of the enterprise, etc.

Since the volume of output can be large, the profit from its sale can be many times higher than the value of intellectual property rights in the case of transfer of rights to use the intellectual property or the sale of these rights.

Of course, this method of commercialization is associated with significant start-up costs for the completion of intellectual property, development of production technology and so on. But in case of success, the sale of manufactured products compensates for these costs and, in addition, will receive a significant profit.

If the right holder does not intend to use intellectual property in his own production or start a new business or create a joint venture, he may transfer all or part of the ownership of the intellectual property to another individual or legal entity.

The sale of rights in full is mostly carried out through a contract of sale, under which as a result of the transfer of ownership of an intellectual property object (sale of a security document - patent or certificate) the holder as the selling party loses all property rights to it. That is, if a patent for an invention is sold, it is re-registered in the name of the new right holder and all property rights to this object pass to the latter.

But more often only the right to use an intellectual property object is transferred, as this is a more advantageous agreement for the owner of the intellectual property object.

The right holder of any object of industrial property (licensor) may sell the license (issue a permit for the use of intellectual property) to any person (licensee), if he does not want or is not able to use the object.

By selling a license, they pursue the goal of making a profit without losing capital for production and market development. Selling a license is a way to introduce technology to the market without selling marketable products. Revenues from the sale of licenses cover legal or natural persons for their research expenses. 
The fact of sale or purchase of a license is legally formalized by a license agreement, which differs from other purchase and sale agreements by the fact that an intangible object is sold or purchased. The licensee acquires the right to use the object of intellectual property only in the territory stipulated by the license agreement and for a certain period.

Leasing is a relatively new form of commercialization of intellectual property rights. Under the leasing agreement, various technological equipment, machines, devices, etc. are transferred, which are made at the level of inventions and are protected by patents. That is, together with the technological equipment and process, the right to use the object of intellectual property is transferred.

The choice of such a form of commercialization as leasing allows start-up entrepreneurs to open and expand their business even in the presence of rather limited start-up capital, promptly using modern achievements of scientific and technological progress in production.

Conclusions. In the context of our study, summarizing the above theses, we can eradicate the following legal forms of use of intellectual property:

1) agreement on inclusion in the authorized capital of property rights to intellectual property;

2) agreements on the introduction into production of intellectual property;

3) an agreement on the distribution of property rights to intellectual property between the employee and the employer;

4) agreements on the disposal of property rights to intellectual property;

5) other agreements that do not contradict the norms of the current legislation of Ukraine.

It should be noted that the legislation does not address the issue of the possibility of commercialization of intellectual property created by state research institutions funded by the State Budget of Ukraine. This issue today worries not only scientists but also business structures that are willing to invest in the development of science and technology, but there are no relevant rules in the legislation today.

\section{Bibliography}

1. Цивільне право України. Особлива частина : підручник / за ред. О. В. Дзери, Н. С. Кузнєцової, Р. А. Майданника. 3-тє видання, перероблене і доповнене. К. : Юрінком Інтер, 2010. 1176 с.

2. Экономическая энциклопедия / Ин-тут экономики РАН ; гл.ред. Л. И. Абалкин. Москва : Экономика, 1999. 1279 с.

3. Прахов Б. Г. Інтелектуальна власність у діяльності підприємств. Питання інтелектуальної власнос$m i$ : зб.наук.праць НДІ інтел. власн. АПрН України. Київ : НДІ ІВ АПрН України, 2005. Вип. 3. 306 с.

\section{Summary}

Begova T. I. Features of use of intellectual property objects: legal bases and procedure. - Article.

The article is devoted to the main problems of legal support of the use of intellectual property. The author analyzes the legislation in the field of intellectual property, the legal nature of the concept of 'use of intellectual property', as well as its forms. Proposals on types of forms of use of intellectual property objects are provided and proposals on further improvement of legislation in this area are formulated.

Today, very relevant is the question of commercialization of intellectual property. A necessary prerequisite is for profit is to use the property, putting it into circulation. 
Ways of using intellectual property are enshrined in Art. 426 of the Civil Code of Ukraine. It also enshrines one of the main postulates of the procedure for the transfer of intellectual property rights: the use of intellectual property by another person is carried out with the permission of the person who has the exclusive right to allow its use, except in cases of lawful use without such permission.

In particular, the legal form of the use of intellectual property by the following attributes: 1) agreement on the introduction of the authorized capital property rights to intellectual property; 2) contracts for manufacturing application of intellectual property; 3) agreement on the distribution of property rights to intellectual property between the employee and the employer; 4) contracts for the disposal of property rights to intellectual property; 5) other contracts that do not contradict the laws of Ukraine.

This attention is focused on the fact that not solved the possibility of commercialization of intellectual property created by public research institutions financed from the State Budget of Ukraine.

Key words: intellectual property, intellectual property, use of intellectual property, scientific and technical activities, invention, utility model.

\section{Анотація}

Бєгова Т. І. Особливості використання об’єктів інтелектуальної власності: правові підстави та процедура. - Стаття.

Стаття присвячена основним проблемам правового забезпечення використання об'єктів інтелектуальної власності. Авторкою проаналізовано законодавство у сфері інтелектуальної власності, правову природу поняття «використання об'єктів інтелектуальної власності», а також його форми. Надано пропозиції щодо видів форм використання об’єктів інтелектуальної власності та сформульовані пропозиції щодо подальшого вдосконалення законодавства у цій сфері.

Сьогодні дуже актуальним є питання комерціалізації інтелектуальної власності, а необхідною передумовою отримання прибутку є використання майна, введення його в обіг.

Способи використання об'єктів інтелектуальної власності закріплені у ст. 426 ЦК України. До ознак договорів щодо розпорядження майновими права інтелектуальної власності відносяться: 1) сам об'єкт договору - нематеріальні блага; 2) той факт, що використання об'єкта інтелектуальної власності можливе лише на підставі договору користувача з правоволодільцем зазначеного об'єкта; 3) їх оплатний характер; 4) суттєві обмеження містяться в законодавстві щодо використання об'єктів інтелектуальної власності, які визнані в установленому порядку секретними; 5) до особливостей цих договорів слід віднести також те, що одним із пунктів такого договору є результати інтелектуальної власності.

Правова форма використання інтелектуальної власності за такими ознаками: 1) договір про введення статутного капіталу майнових прав на об'єкти інтелектуальної власності; 2) договори на виробниче застосування об’єктів інтелектуальної власності; 3) договір про розподіл майнових прав на об'єкти інтелектуальної власності між працівником і роботодавцем; 4) договори розпорядження майновими правами на об'єкти інтелектуальної власності; 5) інші договори, що не суперечать законодавству України.

Ключові слова: інтелектуальна власність, об’єкти інтелектуальної власності, використання об'єктів інтелектуальної власності, науково-технічна діяльність, винахід, корисна модель. 